УДК 378.811

\title{
СУЧАСНИЙ СТАН ДОСЛІДЖЕНОСТІ ПРОБЛЕМИ ФОРМУВАННЯ У МАЙБУТНІХ ВИКЛАДАЧІВ АНГЛІЙСЬКОЇ МОВИ МЕТОДИЧНОЇ КОНТРОЛЬНО-ОЦІНЮВАЛЬНОЇ КОМПЕТЕНТНОСТІ
}

\author{
Українська О. О. \\ ukrolga1981@gmail.com \\ Київський наиіональний лінгвістичний університет \\ Харківський наиіональний педагогічний університет імені Григорія Сковороди \\ Дата надходження 30.04.2018. Рекомендовано до друку 29.05.2018.
}

\begin{abstract}
Анотація. У статті пропонується огляд сучасного стану дослідженості проблеми формування у майбутніх викладачів англійської мови методичної контрольно-оцінювальної компетентності. Визначається місце контрольно-оцінювальної компетентності в професійній підготовці майбутніх викладачів. Описується походження терміна “оцінювальна компетентність” і подається його сучасне визначення. Аналізуються типи знань, необхідних для здійснення ефективного контролю. Розглядаються основні тенденції дослідження проблеми. Окреслюєтеся зміст навчальної вибіркової дисципліни з контролю й тестування.

Ключові слова: контроль, тестування, контрольно-оцінювальна компетентність, укладання контрольних матеріалів, майбутні викладачі.
\end{abstract}

Украинская О. А. Киевский национальный лингвистический университет, Харьковский национальный педагогический университет имени Г. С. Сковороды

Современное состояние исследованности проблемы формирования у будущих преподавателей английского языка методической контрольно-оценочной компетентности

Аннотация. В статье предлагается обзор состояния исследованности проблемы формирования у будущих преподавателей английского языка методической контрольно-оценочной компетентности. Определяется место контрольно-оценочной компетентности в профессиональной подготовке будущих преподавателей. Описывается происхождение термина “оценочная компетентность” и дается его современное определение. Анализируются типы знаний, необходимых для реализации эффективного контроля. Рассматриваются основные тенденции исследования данной проблемы. Описывается содержание учебной дисциплины по выбору по контролю и тестированию.

Ключевые слова: контроль, тестирование, контрольно-оценочная компетентность, составление контрольных материалов, будущие преподаватели.

Ukrayinska O. Kyiv National Linguistic University, Kharkiv Skovoroda National Pedagogical University Study of the current researches of developing English language assessment literacy of pre-service teachers Abstract. Introduction. The article deals with the problem of developing language assessment literacy. The problem of insufficient preparation of English teachers for carrying out assessment at Ukrainian universities is under analysis. Purpose. The purpose of the article is to study the current researches of developing language assessment literacy of pre-service teachers and to reveal the courses taught in Ukraine to develop the target competence. Methods. The current research is based on using the methods as follows: studying and analyzing and generalizing of current scientific publications dedicated to language assessment literacy. Results. There has been revealed the origin of the term "assessment literacy" and its evolution has been considered. The areas concerning the target competence have been defined. Courses aimed at introduction to assessment and testing at Ukrainian universities are enumerated. Main tendencies in researching assessment literacy are offered. The scope of tasks for further research has been defined. The outline of a special course for training pre-service teachers has been provided. Conclusion. To sum up, language assessment literacy is essential in modern educational context. Although there are numerous researches dedicated to this issue, they mainly present questions for consideration and challenges to be dealt with. As there has not been found any evidence of theoretical groundworks and practical recommendations as for developing pre-service teachers' assessment literacy, it necessitates creating the ones.

Key words: assessment, testing, language assessment literacy, design of test tasks, pre-service teachers. 
Постановка проблеми. Вже майже півстоліття не слабшає, а зростає інтерес до проблеми контролю в навчанні англійської мови (АМ). Незважаючи на численні дослідження різноманітних аспектів контролю, як то: фундаментальних основ контролю й тестування, контролю / тестування видів мовленнєвої діяльності й мовленнєвих навичок, навчальних цілей контролю - проблема залишається невирішеною. Виникають питання щодо валідації тестових завдань, переглядаються об'єкти контролю з огляду на зміну освітніх парадигм, пропонуються нові форми надання зворотного зв'язку за результатами контролю, з'являються нові аспекти. Зокрема з розвитком інформаційних технологій комп’ютерне тестування привертає більшу увагу дослідників, розробляються методики так званого альтернативного контролю (взаємооцінювання й самооцінювання). Також останнім часом проблема підготовки викладачів до здійснення контролю стає об’єктом активного дослідження, адже триває пошук нових шляхів підвищення об'єктивності вимірювання рівня навчальних досягнень тих, хто вивчає АМ. Тоді як таку підготовку можуть забезпечити педагогічні заклади вищої освіти (3ВО). Отже, виникає потреба в укладанні теоретичних засад і розробленні методики відповідного навчання. Актуальність дослідження зумовлена соціальним замовленням суспільства на забезпечення якості освіти у ЗВО, недостатньою розробленістю проблеми регламентації контрольно-оцінювальної діяльності викладачів АМ і потребою в методиці поетапного формування їхньої контрольнооцінювальної компетентності.

Метою статті $\epsilon$ вивчити сучасний стан дослідженості проблеми формування у майбутніх викладачів АМ методичної контрольно-оцінювальної компетентності.

Аналіз останніх досліджень і публікацій. Чимало досліджень присвячено структурі й змісту методичної компетентності вчителів / викладачів АМ. Однак, зважаючи на мету нашого дослідження, ми зосередились на виявленні компонентів контрольно-оцінювальної діяльності у структурі професійної компетентності педагога й методичної компетентності викладача іноземної мови (IM). Так, аналіз досліджень дав нам змогу виділити такі тенденції:

- відсутність будь-якого згадування компонентів контрольно-оцінювальної діяльності;

- виокремлення оцінної компетентності в складі професійної компетентності педагогів (не як частини їхньої методичної компетентності);

- включення окремих контрольно-оцінювальних умінь до складу методичної компетентності;

- виокремлення іншомовної контрольно-оцінювальної грамотності (компетентності) (language assessment literacy) у складі професійної компетентності вчителя / викладача IM.

Сам термін “оцінювальна компетентність / грамотність” (assessment literacy) ввів до обігу Р.Д. Стіггінс (Stiggins, 1991) ще у 1991 році для позначення низки вмінь і знань, необхідних для ефективного планування контрольних заходів, ї проведення, інтерпретації й застосування результатів контролю. 3 того часу дослідники інтенсивно займаються вивченням цього явища, пропонують власні визначення, доповнюють структуру названої компетентності, пропонують шляхи її формування. В психолого-педагогічних дослідженнях оцінювальну компетентність включено до складу професійної компетентності педагогів для позначення їхньої готовності до здійснення оцінювання навчальних досягнень тих, які навчаються. Більшість педагогів пропонують формувати таку компетентність у межах підвищення кваліфікації вчителів / викладачів, які вже працюють і мають певний професійний досвід.

Найповнішим з огляду на відповідність сучасним вимогам вищої освіти, на нашу думку, $€$ визначення оиінювальної компетентності Т.Є. Ісаєвої, яка ним позначає здатність викладача розробляти або вибирати контрольно-вимірювальні матеріали з метою оцінювання рівня сформованості компетентностей студентів і встановлення відповідності цього рівня до вимог, зазначених у державних стандартах, оскільки ці матеріали надають можливість повно й системно оцінити готовність випускника ЗВО до виконання основних функцій сфери його майбутньої професійної діяльності (Исаева, 2014). 
Між тим, запропоновані вченими методики формування оцінювальної компетентності не враховують зміст тієї чи іншої навчальної дисципліни й специфіку ії викладання, а містять загальнопедагогічні положення, що дають змогу викладачу створити оптимальні педагогічні умови для здійснення ефективного контролю, але не надають опису технології укладання якісних контрольних матеріалів 3 конкретної навчальної дисципліни. Не виникає сумніву, що для організації ефективного контролю рівня навчальних досягнень студентів у певній галузі викладачеві необхідне ще й знання цільової навчальної дисципліни й знання з методики iii навчання. Тому ми пропонуємо називати оцінювальну компетентність викладача АМ методичною контрольно-оцінювальною компетентністю.

Аналіз фундаментальної літератури 3 контролю, тестування в навчанні АМ свідчить про те, що для сформованості компетентності в здійсненні ефективного контролю / оцінювання викладачеві необхідні знання з різноманітних галузей науки, а саме: педагогіки (створення педагогічних умов для проведення контрольних заходів), психології (укладання конструкту, етичність у відборі тем для завдань, стандартизація поведінки екзаменаторів, надання зворотного зв'язку), лінгвістики (укладання контрольних матеріалів: відбір (аудіо)текстів, написання інструкцій для завдань, створення завдань, перевірка письмових робіт з відкритою відповіддю, проведення й оцінювання усного опитування), методики викладання АМ (укладання конструкту, створення контрольних завдань, укладання / використання аналітичних і критеріальних шкал оцінювання, оцінювання відкритих усних і письмових відповідей), інформаційних технологій (пошук матеріалів для створення контрольних завдань, проведення автоматизованого контролю, аналіз результатів тестування), соціології (проведення опитувань, анкетування, визначення потреб цільової групи, урахування гендерних характеристик тестованих) i, навіть, математики (статистичний аналіз результатів тестування) (Миролюбов, 1999; Петращук, 1999; Alderson, Clapham \& Wall, 2005; Bachman \& Palmer, 2000; Cheng \& Fox, 2017; McNamara, 2000).

Таку всебічну підготовку за кордоном (майбутнім) учителям / викладачам АМ забезпечують, наприклад, у Ланкастерському та Бедфордширському університетах (Англія). Тоді як в Україні підготовка магістерських програм 3 освітніх вимірювань ведеться щонайменше в п'яти університетах кафедрами комп'ютерно-інформаційних технологій - Національному педагогічному університеті імені М. П. Драгоманова, Центральноукраїнському державному педагогічному університеті імені Володимира Винниченка, Ніжинському державному університеті імені Миколи Гоголя, Черкаському національному університеті імені Богдана Хмельницького, Одеській державній академії технічного регулювання та якості, де слухачі отримують теоретичну підготовку в галузі педагогічного оцінювання й випускаються фахівцями 3 науково-технічної інформації. Щодо спеціалістів з оцінювання в галузі навчання АМ, то в Україні така підготовка здійснюється на освітньо-кваліфікаційному рівні “бакалавр” або “магістр” щонайменше в шести університетах - Київському національному лінгвістичному університеті, Харківському національному педагогічному університеті імені Г. С. Сковороди, Прикарпатському національному університеті імені Василя Стефаника, Центральноукраїнському державному педагогічному університеті імені Володимира Винниченка, Кам'янець-Подільському національному університеті імені Івана Огієнка, Мукачівському державному університеті - в межах курсів за вибором “Вступ до тестології”, “Тестування в методиці навчання іноземних мов”, “Вступ до мовного тестування й оцінювання”, “Міжнародні системи тестування з англійської мови”. Безумовно, викладання цих дисциплін сприяє формуванню обізнаності майбутніх учителів / викладачів АМ у контрольно-оцінювальній діяльності, однак вони не мають на меті навчати студентів педагогічного дизайну з укладання контрольно-оцінювальних матеріалів. Тоді як зарубіжні дослідники (Б. О’Салліван, Д. Тцагарі, Г. Фулчер та ін.) під контрольнооцінювальною компетентністю розуміють здібність розробляти як окремі контрольні завдання, так і контрольні комплекси (Cheng \& Fox, 2017; Fulcher, 2012; Fulcher \& Davidson, 2007; 
Tsagari \& Vogt, 2017). Визначення іншомовної контрольно-оцінювальної компетентності Г. Фулчером на сьогодні вважається найточнішим. Дослідник визначає їі як знання, навички й уміння, необхідні для планування, розроблення, проведення й аналізу стандартизованого контролю та/або контролю навчальних досягнень у закладах освіти, обізнаність 3 процедурами тестування й відповідними принципами та підходами, здібність оцінити вплив результатів контролю на всі зацікавлені сторони та бути відповідальними за якість розроблених тестів (Fulcher, 2012, p. 125).

В. Беррі та Б. О'Салліван провели аналіз потреб учителів / викладачів ІМ у здійсненні ефективного контролю та виділили галузі необхідних для цього знань. Дослідники дійшли висновку, що саме в учителів / викладачів контрольно-оцінювальна компетентність має бути сформована на середньому рівні, так звана функціональна компетентність. Пи цьому, слідом за Л. Тейлор, дослідники надають перевагу передусім знанням з педагогіки, технічним умінням, особистому ставленню й знанням навчального контексту, лише потім соціокультурним знанням, теоретичним знанням у галузі контролю та виставленню балів та прийняттю рішень на основі отриманих результатів.

Також Д. Тсагарі та К. Вогт слідом за Г. Фулчером та А. Хасселгрін, К. Карлсен, Х. Хелнесс провели широкомасштабне опитування вчителів / викладачів у низці європейських й азіатських країн, метою якого було встановити рівень сформованості їхньої контрольно-оцінювальної компетентності та з'ясувати індивідуальні потреби в підготовці до контролю й оцінювання в межах підвищення кваліфікації (Fulcher, 2012; Hasselgreen, Carlsen \& Helness, 2004; Tsagari, \& Vogt, 2017). Як свідчать результати опитування, лише обмежена кількість респондентів отримали базову підготовку в ЗВО, тому загалом вони мають низький рівень сформованості компетентності й досі використовують переважно паперові тести. Проте позитивним дослідниці вважають порівняння відповідей студентів зі стандартами й застосування альтернативних форм контролю.

Багато зарубіжних робіт присвячено дослідженню англомовної контрольно-оцінювальної компетентності, чимало 3 яких фокусуються на підготовці фахівців 3 міжнародних стандартизованих тестів (IELTS, Cambridge Suite of Examinations, TOEFL). Така увага пояснюються комерційним попитом на ці іспити. Українські вчителі / викладачі АМ теж широко їх застосовують для навчання й контролю. Контролю навчальних досягнень у закладах освіти теж присвячено численні дослідження, в яких розглядаються різноманітні аспекти цієї проблеми.

Так, А. Скаріно (Scarino, 2017) в руслі глобалізації досліджує можливість оцінювання шкільними вчителями міжкультурної компетентності учнів у багатонаціональних класах. Авторка зауважує, що всі сучасні навчальні плани передбачають оцінювання чотирьох мовленнєвих умінь, тоді як сучасна реальність вимагає від користувачів АМ не розуміння смислу почутого / прочитаного, а вміння інтерпретувати інші культури й розмірковувати про власну культуру й чужі культури, не порівнюючи їх. Спираючись на спостереження австралійських учителів, дослідниця доводить, що під час взаємодії учні, представники різних культур, здобувають знання, проте які не $є$ важливим, оскільки вагомим $€$ саме процес розмірковування учнів, що й $є$ міжкультурною компетентністю, яка має підлягати оцінюванню.

К. Хілл наполягає на важливості формування контрольно-оцінювальної компетентності ще у ЗВО, пояснюючи це тим, що контроль має свої особливості залежно від контексту проведення, а це, в свою чергу, вимагає знання міжнародних, національних і регіональних освітніх стандартів, які, до речі, можуть значно відрізнятися один від одного (Hill, 2017). Дослідниця відзначає велике значення контролю в наш час, значну відповідальність, яку вчителі несуть за результати контролю. Авторка відмічає також позитивний вплив досвіду використання вчителями АМ на уроках міжнародних стандартизованих тестів, які є еталонами якості.

Розглянемо методики, спрямовані на розвиток цільової компетентності. О.І. Ніконова (Никонова, 2014) розробила методику формування у майбутніх учителів IM компетентностей 
у здійсненні контролю мовленнєвих умінь учнів. Дослідниця виділила компоненти цієї компетентності: мотиваційний, когнітивний, комунікативний, проектувальний, організаторський, діагностичний, рефлексивний і креативний, при цьому виокремивши діагностичну компетентність як найбільш значущу для контролю мовленнєвих умінь. Авторський курс призначено для бакалаврів педагогічної освіти й учителів курсів підвищення кваліфікації.

А.В. Матієнко (Матиенко, 2012) розробила методику формування у майбутніх учителів контрольно-вимірювальної компетентності як засіб пізнавальних і комунікативних резервів особистості здійснювати тривалий моніторинг для вимірювання власних навчальних досягнень за допомогою індивідуальних навчально-тестових портфелів. Методика передбачає ознайомлення студентів 3 тестовими стратегіями, розвиток їх самоконтролю. Авторка рекомендує студентам вести щоденник спостережень за формуванням власної комунікативної й тестової компетентностей. Окрім цього, студенти мають індивідуальні навчально-тестові портфелі, які є формою зберігання виконаних завдань, матеріалу для аналізу й підставою для педагогічного судження про навчальні досягнення.

У деяких дослідників (Т. О. Лукіна, А. В. Матієнко, Р. П. Мільруд та ін.) знаходимо інший підхід до трактування тестової компетентності (test wiseness), зокрема щодо студентів як суб'єктів навчальної діяльності. Це їхня обізнаність про стратегії складання тестових завдань, уміння знайти правильну відповідь, спираючись на свої знання структури й характеристик завдань, знання алгоритмів виконання завдання, що їм допомагає отримати вищий бал незалежно від їхнього реального рівня володіння IM. Зазвичай укладачі тестів намагаються уникати випадків, коли той чи інший варіант відповіді відрізняється від інших своїми характеристиками, наприклад довжиною або загальнішою природою, дотримуються одноманітності, але не завжди це досягається. 3 іншого боку, вважаємо корисним для майбутніх викладачів володіння такими стратегіями в подальшій професійній діяльності для укладання якісних завдань, оскільки вони вже будуть добре знати, чого очікувати від своїх учнів, і зможуть уникнути дизайнерських помилок.

Основні результати дослідження. Отже, контрольно-оцінювальна компетентність майбутніх викладачів за своєю природою $€$ міждисциплінарною. Її всебічне цілісне формування можливе лише комплексно в межах дисциплін загального, мовного, психолого-педагогічного, методичного спрямування, як-то на мовних заняттях, в курсі “Оцінювання" з педагогіки, методичного курсу 3 контролю й тестування, при вивченні інформаційних технологій та математичної статистики. Адже для організації ефективного контролю навчальних досягнень викладачеві потрібен високий рівень володіння АМ, знання принципів укладання чи добирання контрольних матеріалів, володіння методами статистичної обробки отриманих результатів. Однак існує точка зору, що статистичні дані, отримані при аналізі кількості робіт меншої ніж 30-50, не $\epsilon$ валідними, тому для контролю навчальних досягнень не рекомендують застосовувати методи математичного обчислювання. В цьому разі викладання основ такого аналізу може виявитися надмірним. Тобто нагальними завданнями $є$ встановити обсяг виучуваного матеріалу й окреслити зміст навчальної дисципліни. Одним із варіантів організації навчального часу може бути виділення більшої кількості годин на опрацювання теми зі створення контрольних завдань. Для розумного розподілу часу на необхідні види діяльності доцільним вважаємо ретельний аналіз наявних визначень контрольно-оцінювальної компетентності з подальшим виділенням структурних компонентів цього явища.

Щодо виділення міжкультурної компетентності як об'єкта контролю ми маємо певні зауваження з огляду на ситуацію, що склалась у вітчизняних ЗВО. Так, академічні групи зазвичай більш-менш монокультурні, тому дуже складно організувати такий контроль, який описаний в австралійських школах. Це питання потребує окремого дослідження. Вбачаємо можливим упровадити новий об'єкт контролю через використання різноманітних текстів для читання й аудіювання, які містять інформацію про інші культури. 
На відміну від учителів Європи й Азії, опитаних Д. Тсагарі та К. Вогт про їхній рівень сформованості контрольно-оцінювальної діяльності, наші викладачі здебільшого добре знайомі зі стандартизованими тестами міжнародних екзаменаційних комісій, оскільки готують молодь до складання цих іспитів й активно використовують готові тести в освітньому процесі. Отже, нагальною $є$ підготовка фахівців, здатних укладати власні контрольні матеріали. Для цього слід розробити комплекси вправ, спрямовані на розвиток відповідних умінь. Вважаємо, що в межах вибіркової дисципліни курсу методики можливо навчати дидактизації текстів, укладанню рубрик, які пізніше увійшли б в індивідуальні банки тестових завдань кожного студента. Однак ми не виявили методик, які б навчали таких умінь. Також перспективним є подальше ознайомлення з англомовною термінологією 3 контролю й оцінювання, розуміння рівнів володіння IM, ознайомлення з різними формами контролю, типами контрольних завдань. Студентам слід надати можливість спробувати себе в ролі вчителя до того, як вони підуть до шкіл, оскільки термін педагогічної практики є обмеженим. Корисним був би досвід перевірки письмових робіт, оцінювання усних відповідей за критеріями, надання зворотного зв'язку за результатами перевірки.

Висновки і перспективи подальших розвідок. Таким чином, здатність викладачів до контрольно-оцінювальної діяльності $є$ вимогою сьогодення. Наразі нами не виявлено ні розроблених теоретичних основ, ні практичних рекомендацій щодо навчання магістрів, майбутніх викладачів AM, правильної організації контролю на мовному факультеті, тому перспективу подальших досліджень вбачаємо в розробленні методики формування в майбутніх викладачів АМ контрольно-оцінювальної компетентності під час їх навчання в магістратурі, зокрема в межах вибіркових дисциплін.

\section{ЛІТЕРАТУРА}

Исаева, Т. Е. (2014). Оценочная компетенция вузовского преподавателя: содержание и смысл. Педагогика высшей школь "Высшее образование в России", 10, 106-112.

Матиенко, А. В. (2012). Методическая концепщия когнитивно-коммуникативного контроля в системе обучения иностранному языку студентов лингвистического вуза (Докторская диссертация). ФГБОУ ВПО “Нижегородский государственный лингвистический университет имени Н. А. Добролюбова”, Нижний Новгород, Российская Федерация.

Миролюбов, А. А. (1999). Вопросы контроля обученности учащихся иностранному языку. Обнинск: Титул, 1999.

Никонова, Е. И. (2014). Методика формирования компетентностей учителя иностранного языка в области осуществления контроля речевых умений учащихся (Автореферат кандидатской диссертации). ФГБОУ ВПО “Московский государственный гуманитарный университет имени М.А. Шолохова”, Москва, Российская Федерация.

Петращук, О. П. (1999). Тестовий контроль у навчанні іноземної мови в середній загальноосвітній школі. Київ, Україна: Вид. центр КДЛУ.

Alderson, Ch. J., Clapham, C. \& Wall, D. (2005). Language Test Construction and Evaluation. Cambridge, UK: Cambridge University Press.

Bachman, L. F. \& Palmer, A. S. (2000). Language Testing in Practice. Hong Kong, China: Oxford University Press.

Cheng, L. \& Fox, J. (2017). Assessment in the Language Classroom. London, UK: Macmillan education, Palgrave.

Fulcher, G. (2012). Assessment Literacy for the Language Classroom. Language Assessment Quarterly, 9(2), 113-132.

Fulcher, G. \& Davidson, F. (2007). Language Testing and Assessment an advanced resource book. London, New York: Routledge. 
Hasselgreen, A., Carlsen, C. \& Helness, H. (2004). European Survey of Language and Assessment Needs. Part One: General Findings. Retrieved from: http://www.ealta.eu.org/documents/resources/ survey-report-pt1.pdf.

Hill, K. (2017). Language Assessment Literacy - scoping the territory. Papers in Language Testing and Assessment, 6(1), iv-vii.

McNamara, T. (2000). Language Testing. Hong Kong: Oxford University Press.

Scarino, A. (2017). Developing assessment literacy of teachers of languages: A conceptual and interpretive challenge. Papers in Language Testing and Assessment, 6(1), 18-40.

Stiggins, R. J. (1991). Assessmentliteracy. Phi Delta Kappan, 72(7), 534-539.

Tsagari, D. \& Vogt, K. (2017). Assessment Literacy of Foreign Language Teachers around Europe: Research, Challenges and Future Prospects. Papers in Language Testing and Assessment, 6(1), 41-63.

\section{REFERENCES}

Isaeva, T. E. (2014). Ocenochnaja kompetencija vuzovskogo prepodavatelja: soderzhanie i smysl. Pedagogika vysshej shkoly "Vysshee obrazovanie v Rossii", 10, 106-112.

Matienko, A. V. (2012). Metodicheskaja koncepcija kognitivno-kommunikativnogo kontrolja v sisteme obuchenija inostrannomu jazyku studentov lingvisticheskogo vuza (Doktorskaja dissertacija). FGBOU VPO "Nizhegorodskij gosudarstvennyj lingvisticheskij universitet imeni N. A. Dobroljubova", Nizhnij Novgorod, Rossijskaja Federacija.

Miroljubov, A. A. (1999). Voprosy kontrolja obuchennosti uchashhihsja inostrannomu jaziku. Obninsk: Titul, 1999.

Nikonova, E. I. (2014). Metodika formirovanija kompetentnostej uchitelja inostrannogo jazyka v oblasti osushhestvlenija kontrolja rechevyh umenij uchashhihsja (Avtoreferat kandidatskoj dissertacii). FGBOU VPO "Moskovskij gosudarstvennyj gumanitarnyj universitet imeni M.A. Sholohova", Moskva, Rossijskaja Federacija.

Petraschuk, O. P. (1999). Testovyj kontrol' u navchanni inozemnoi movy v serednij zahal'noosvitnij shkoli. Kyiv, Ukraina: Vyd. tsentr KDLU.

Alderson, Ch. J., Clapham, C. \& Wall, D. (2005). Language Test Construction and Evaluation. Cambridge, UK: Cambridge University Press.

Bachman, L. F. \& Palmer, A. S. (2000). Language Testing in Practice. Hong Kong, China: Oxford University Press.

Cheng, L. \& Fox, J. (2017). Assessment in the Language Classroom. London, UK: Macmillan education, Palgrave.

Fulcher, G. (2012). Assessment Literacy for the Language Classroom. Language Assessment Quarterly, 9(2), 113-132.

Fulcher, G. \& Davidson, F. (2007). Language Testing and Assessment an advanced resource book. London, New York: Routledge.

Hasselgreen, A., Carlsen, C. \& Helness, H. (2004). European Survey of Language and Assessment Needs. Part One: General Findings. Retrieved from: http://www.ealta.eu.org/documents/resources/ survey-report-pt1.pdf.

Hill, K. (2017). Language Assessment Literacy - scoping the territory. Papers in Language Testing and Assessment, 6(1), iv-vii.

McNamara, T. (2000). Language Testing. Hong Kong: Oxford University Press.

Scarino, A. (2017). Developing assessment literacy of teachers of languages: A conceptual and interpretive challenge. Papers in Language Testing and Assessment, 6(1), 18-40.

Stiggins, R. J. (1991). Assessmentliteracy. Phi Delta Kappan, 72(7), 534-539.

Tsagari, D. \& Vogt, K. (2017). Assessment Literacy of Foreign Language Teachers around Europe: Research, Challenges and Future Prospects. Papers in Language Testing and Assessment, 6(1), 41-63. 